\title{
Roundtable
}

\section{Response to Bagavathiannan and Van Acker's "Transgenes and national boundaries - The need for international regulations": Biotechnology developers and regulators already consider transgene movement across national boundaries and the environmental risks posed by adventitious presence of unapproved events are overstated}

\author{
Thomas E. NICKSON ${ }^{1 *}$ and Alan F. RAYBOULD ${ }^{2}$ \\ 1 Monsanto Company, St. Louis, MO, 63167, USA \\ 2 Syngenta, Jealott's Hill International Research Centre, Bracknell, RG42 6EY, UK
}

\begin{abstract}
Bagavathiannan and Van Acker propose greater international cooperation and information sharing in risk assessment for biotechnology-derived crops because pollen- and seed-mediated gene flow across political boundaries may lead to the adventitious presence of unapproved transgenes at sites along the borders of neighboring countries. However, they fail to convince us that something is wrong with the current situation and provide no details of how it could be improved.
\end{abstract}

Keywords: gene flow / alfalfa / international regulatory policy / environmental risk

Bagavathiannan and Van Acker (2009) propose greater international cooperation and information sharing in risk assessment for biotechnology-derived crops because pollen- and seed-mediated gene flow across political boundaries may lead to the adventitious presence of unapproved transgenes at sites along the borders of neighboring countries. They cite Roundup Ready ${ }^{\circledR}$ alfalfa cultivation in US fields adjacent to the Canadian border as a case-in-point. We contend that Bagavathiannan and Van Acker's analysis is misleading and implies that the possibility of gene flow from GM crops across borders is ignored by registrants and poses risks that are not adequately evaluated by national risk assessments. Furthermore, their commentary has factual inaccuracies and incomplete descriptions of the science associated with gene flow. Finally, we believe that its policy implications are inappropriate and unrealistic.

While Bagavathiannan and Van Acker make a valid point about the potential regulatory significance of the movement of transgenes across international borders, their commentary fails to place the

*Corresponding author: thomas.nickson@monsanto.com problem in its proper context. First, they assert that "in the US, genetically modified (GM) glyphosateresistant alfalfa (Medicago sativa, L.) has been deregulated", but "it has not been approved for commercial cultivation in Canada". This is only a half-truth because they fail to note that Roundup Ready alfalfa has been approved for environmental release in Canada since July 28, 2005 (http://www.inspection.gc. ca/english/plaveg/bio/dd/dd0553e.shtml). Regulatory approvals necessary for variety registration and herbicide application have not been obtained to date, and it is not decided yet if commercial approvals will be sought. Application for environmental approval of Roundup Ready alfalfa in Canada (separate from variety and herbicide registrations) indicates that the implications of movement of transgenes across international borders are already considered by companies that routinely apply for regulatory approvals in countries that may receive transgenic pollen or seed through the normal agronomic practices of a neighboring country (see http://www.croplife.ca/web/english/stewardship/ seed_marketing_distribution.cfm). Member companies of CropLife International are committed to stewarding 
their GM products to ensure regulatory compliance while protecting trade. The case of alfalfa in North America shows that registrants recognize the potential for movement of viable plant materials across borders and seek appropriate regulatory approvals for their regulated products. Approvals for Roundup Ready alfalfa were requested in Canada because it was known that viable material would likely move there through seed and forage export channels despite the fact that a final decision had not been made concerning marketing.

Registrants and regulators are aware of the potential for pollen and seed-mediated movement of GM crops across international borders and seek to minimize the adventitious presence of unapproved events using a variety of approaches; however, even if regulatory compliance were to be breached, that does not mean that a serious or unevaluated environmental risks exists as suggested by Bagavathiannan and Van Acker. The adventitious presence of an unapproved event in regions bordering a country where the event is approved for cultivation is unlikely to pose a meaningful environmental risk unless two conditions are met. First, the characteristics of the environment must change significantly at the border. The other condition involves the environmental policies of the two countries; that is to say the protection goals and assessment endpoints of their regulatory risk assessments must fundamentally differ. In the case of the US and Canadian borders, the ecological parameters relevant to a risk assessment are very similar. Although the basis for regulating GM crops is very different in Canada and the US, the two countries have sufficiently similar views on environmental protection to allow discussion of common data requirements for environmental risk assessments of GM crops (http://www.inspection.gc.ca/ english/plaveg/bio/usda/appenannex2e.shtml). Thus even if Roundup Ready alfalfa were not approved in Canada, it would be unreasonable to dismiss the risk assessment conducted in the US as irrelevant for the Canadian environment at the border.

A third concern is Bagavathiannan and Van Acker's omission of some key technical information. On the topic of gene flow from alfalfa, they fail to inform the reader that current forage production methods greatly reduce the probability for pollen and seed production (see http://www.alfalfa.org/pdf/CSExportSeed.pdf), or that seed production in the US occurs in areas far removed from the US/Canadian border. As such, their discussion of the biology of alfalfa in the context of their thesis is incomplete because it omits important mitigating factors. Other scientific information is presented in an incomplete and unsatisfactory manner. For example, the conclusion presented in Table 2 that soybean is a crop "in which international gene flow may be a potential concern" is doubtful given its limited potential for outcrossing (e.g., Ahrent and Caviness, 1994; Ray et al., 2003); similarly, the potential for pollen mediated gene flow in cotton is also limited (e.g., Umbeck et al., 1991; Van Deynze et al., 2005). One must also question the basis for identifying borders like India and China as well as Egypt and Libya to be areas where "international gene flow may be of potential concern" (see their Tab. 2).

Finally, Bagavathiannan and Van Acker inaccurately present important aspects of relevant policies currently in place. Their description of the regulatory policy landscape includes speculation about liability issues and inflammatory terms like "transgene contamination". They assert that there is "a need for international co-operative risk assessment initiatives between the US and Canada". Again, they have failed to note that the United States Department of Agriculture (USDA) and Canadian Food Inspection Agency (CFIA) have been officially engaged in bilateral relations on risk assessment issues with biotech crops since 1998 (http://www.inspection.gc.ca/ english/plaveg/bio/internate.shtml\#cubr). More recently, these discussions have been broadened to include Mexico because all three governments recognize that North American harmonization is an important issue.

In conclusion, Bagavathiannan and Van Acker state that "it is necessary to consider the implementation of additional regulatory measures for growing GM crops in border regions where international gene flow is a possibility"; however, they fail to convince us that something is wrong with the current situation and provide no details of how it could be improved. If Bagavathiannan and Van Acker are implying that governments could negotiate a single, standardized risk assessment approach to the adventitious presence of GM crops at international borders, this would be unprecedented, and perhaps unrealistic and unnecessary. The more effective approach to address adventitious presence is agreement through specific multilateral discussions; however, the substantial progress towards this end in North America was not noted by Bagavathiannan and Van Acker. The alternative of waiting for complete global approvals by dozens of countries would stop the development of potentially beneficial crops and deny millions of growers access to technologies that could improve their production systems. What is more realistic would be for governments to adopt appropriate national regulatory policies for adventitious presence designed to build public confidence that an adequate level of environmental protection is being maintained with minimum necessary disruption to the international trade of seed. Food safety aspects of this issue have been taken up successfully by the Codex Alimentarius, but, with the exception of Canada, environmental adventitious presence policies remain mostly in draft form today (see CFIA website: http://www.inspection.gc. ca/english/plaveg/bio/nonapp/nonappe.shtml). 
Received June 17, 2009; accepted July 13, 2009.

\section{REFERENCES}

Ahrent DK, Caviness CE (1994) Natural cross-pollination of twelve soybean cultivars in Arkansas. Crop Sci. 34: 376-378

Bagavathiannan M, Van Acker R (2009) Transgenes and national boundaries - The need for international regulation. Environ. Biosafety Res. 8, doi:10.1051/ebr/2009011
Ray JD, Kilen TC, Abel CA, Paris RL (2003) Soybean natural cross-pollination rates under field conditions. Environ. Biosafety Res. 2: 133-138

Umbeck PF, Barton KA, Nordheim EV, McCarty JC, Parrott WL, Jenkins JE (1991) Degree of pollen dispersal by insects from a field test of genetically engineered cotton. J. Econ. Entomol. 84: 1943-1950

Van Deynze AE, Sundstrom FJ, Bradford KJ (2005) Pollenmeditated gene flow in California cotton depends on pollinator activity. Crop Sci. 45: 1565-1570 